\title{
FDI in India: Leading to Economic Growth
}

\author{
N. Ramar, V. Prabakaran, S.Rajendran, C.K Muthu Kumaran
}

\begin{abstract}
Foreign Direct Investment (FDI) plays predominant role in the improvement of nation's growth and the global business. Foreign Direct Investment (FDI) is an important tool which is used currently in the overseas market and it is also a key factor which supports the investors to enter into the economy. In the developing countries FDI also enhances the exports made by the manufacturing firms through overflow effects on local companies by the means of exporting activities. There is a direct and indirect effect on the host country's exports to the FDI. New paradigms in the marketing channels can be endorsed due to the help of FDI, access to technology is also possible, product skills and financing could be done easily. Capital is in when domestically available capital is insufficient for the purpose of overall development of the country, foreign capital is seen as a way of filling up this gap. FDI inflows to India remained sluggish, when global FDI flows to EMEs had recovered in 2017- 18, despite sound domestic economic performance ahead of global recovery. This paper gathers evidence through a panel exercise that actual FDI to India during the year 2017-18 fell short of its potential level. An attempt is made through this paper to know the FDI equity inflows from various countries to India. An attempt has been made by the researcher through this paper to examine the economic growth through FDI. For the analysis the statistical tools like one - Way ANOVA, K-S Test has been used and the suggestions and the recommendations are based on the approach.
\end{abstract}

Keywords : FDI, OECD, MNCS, OGL, SIA, FIPB, OCB's, MIGA, NRI's, FEMA, FERA, FIIA, GIIN's, UNCTAD.

\section{INTRODUCTION}

The Foreign Direct Investment (FDI) is a speculation made by an organization or individual in one nation in business premiums in another nation, as either setting up business activities or procuring business resources in the other nation, for example, possession or controlling enthusiasm for a remote organization. Remote direct speculations are recognized from portfolio interests in which a financial specialist just buys values of outside based organizations. The key element of outside direct venture is that it is a speculation made that builds up either viable control of, or if nothing else generous impact over, the basic leadership of a remote business. The economic growth can be certainly attained by Capital formation is a major determinant of economic growth. FDI demonstrates to be an

Revised Manuscript Received on September 25, 2019

Mr. N. Ramar, Research Scholar (Full - Time), Alagappa Institute of Management, Alagappa University, Karaikudi

Mr. V. Prabakaran, Research Scholar (Full - Time), Alagappa Institute of Management, Alagappa University, Karaikudi

Mr.S.Rajendran, Research Scholar (Full - Time), Alagappa Institute of Management, Alagappa University, Karaikudi

Dr. C.K MuthuKumaran, Associate Professor, Alagappa Institute of Management, Alagappa University, Karaikudi imperative source of funds for them. In the existing globalised world there is exponential increase of FDI in both developed and developing countries. FDI has been a foundation of profitable growth for India, believing that in addition needed capital, FDI brings in more than a few benefits. The Indian economy has happen for attracting a superior amount of FDI after 2014, before 2014 the FDI flow was hypocritical between USD 4029 to USD 4322.

The role of Foreign Direct Investment (FDI) in this development is very crucial. It is widely recognized that foreign direct investment (FDI) produces economic benefits to the recipient countries by providing capital, foreign exchange, technology and by enhancing competition and access to foreign markets. The MNC are those kind of Businesses that make FDI are often called multinational corporations (MNCs). An MNC may make a direct investment by creating a new foreign enterprise, which is called a 'Greenfield investment', or by the acquisition of a foreign firm, either called an acquisition or Brownfield investment.

According to the IMF and OECD definitions, direct investment reflects the aim of obtaining a lasting interest by a resident entity of one economy (direct investor) in an enterprise that is resident in another economy (the direct investment enterprise). The -lasting interest implies the existence of a long-term relationship between the direct investor and the direct investment enterprise and a significant degree of influence on the management of the latter. Direct investment involves both the initial transaction establishing the relationship between the investor and the enterprise and all subsequent capital transactions between them and among affiliated enterprises, both incorporated and unincorporated.

\section{OBJECTIVE OF THE STUDY}

This study is based upon the following objectives,

- To determine the factors which influence the FDI inflows in India.

- To analyze the factors that are affecting the FDI inflows and to provide the suitable suggestion.

\section{METHODOLOGY}

Sources of Data Collection - For this study Researcher 
has analyzed, gathered and compiled the various data from the sources like,

$>$ Handbook on Statistics of Indian Economy, RBI, Various Issues.

$>$ Economic Survey 2010 - 2018, Government of India.

$>$ DIPP (Department of Industrial Policy and Promotion)

\section{CSO (Central Statistical Organization)}

Period of Study - Under this study, Researcher has chosen from 2010 - 2018. Period of Nine years has been selected to know the factors that influence the flow of FDI into the country.

Tools Used - For this study some of the tools which are used by the researcher are, Annual Growth Rate, CAGR are used to analyze the magnitude of FDI. Using Correlation the factors that influence the FDI into India could be compared. The One - Way ANOVA is used in this study to determine the significance between the variables.

\section{REVIEW OF LITERATURE}

Birendra Kumar, Surya Dev (2003) ${ }^{1}$, undertook a study entitled "Low Bargaining Power of Labour Attracts Foreign Direct Investment in India", stated that the increasing trend in the absolute wage of the worker.

Sebastin $(\mathbf{2 0 0 4})^{2}$, in their paper it was discussed that the FDI in the countries in India

Peng Hu $(\mathbf{2 0 0 6})^{3}$, in their paper analyzed the various determinants which are directly concerned with the economic growth, domestic demand, currency stability, government policy and inflation rate are affecting the economic growth of the nation. It was also analyzed that most of the factors that are affecting the competitive advantages of the India.

Peter $(\mathbf{2 0 0 8})^{4}$, in their study determined that it is believed widely that the booming FDI in the post - reform India is very important for the economic growth.

Artur, Lokanandha (2009) ${ }^{\mathbf{5}}$, in their study analyzed the determinants of FDI in the Asian economies. Under four heads the determinants were analyzed viz., economic and policy factors, institutional factors, political factors and socioeconomic factors. And, it is found that the major indicators are labour related issues and political issues.

\section{SIGNIFICANCE}

* The corporations extend their business activity into foreign countries through FDI.

* The main object of FDI is to acquire or retain control over markets and/or productive resources.

* Major areas of FDI are: oil, coal and ores, as well as service sector including banking/ finance, legal services, marketing and distribution.

* Capital movement in the form of foreign investment is advantageous to the economies of both the lending and borrowing nations.

* To the lending country, foreign investments may prove to be an additional source of supply of the required products when investment is made in the exporting industries abroad. Lending of capital raises the purchasing power of borrowing nations in the foreign market which may enable the lender country to increase its exports.

* FDI offers number of benefits like overture of new technology, innovative products, and extension of new markets, opportunities of employment and introduction of new skills etc., which reflect in the growth of income of any nation.

* The Growth in economic globalization can be attained through FDI. Investment has always been an issue for the developing economies such as India. The world has been globalizing and all the countries are liberalizing their policies for welcoming investment from countries which are abundant in capital resources

\section{FDI POLICY IN PRE-LIBERALIZATION PERIOD}

Historically, India had followed an extremely cautious and selective approach while formulating FDI policy in view of the dominance of import-substitution strategy of industrialization. With the purpose of fetching self reliant, there was a twin nature of policy intention - FDI through foreign collaboration was much welcomed where high technology and high priorities to make national potential and dispirited in low technology areas to guard and take care of domestic industries.

The regulatory framework was consolidated through the enactment of Foreign Exchange Regulation Act (FERA), 1973 wherein foreign equity holding in a joint venture was allowed only up to 40 per cent. Recognizing these limitations, partial liberalization in the trade and investment policy was introduced in the 1980s with the objective of enhancing export competitiveness, modernization and marketing of exports through Transnational Corporations (TNCs). The policy was characterized by de-licensing of some of the industrial rules 
and promotion of Indian manufacturing exports as well as emphasizing on modernization of industries through liberalized imports of capital goods and technology. This was supported by trade liberalization measures in the form of tariff reduction and shifting of large number of items from import licensing to Open General Licensing (OGL).

\section{ANALYSIS OF FDI INFLOWS IN INDIA}

The primary objective of the study is to determine the FDI inflows. And, in this paper researcher has chosen, the period of study from 2010 - 2011 to 2018 - 2019. The AGR is computed for the stipulated period and it is computed to determine the magnitude of FDI inflows. The Table 1 represents the Annual Growth Rate of the inflows of FDI for each year. And, Compound Annual Growth Rate (CAGR) is computed for the consequent number of years. The Annual Growth Rate is computed using the following formula,

$$
\mathrm{AGR}=(\mathrm{X} 2-\mathrm{X} 1) / \mathrm{X} 1
$$

Where, $\mathrm{X} 1=$ First value of $\mathrm{X}$ variable.

$\mathrm{X} 2=$ Second value of $\mathrm{X}$ variable.

And, CAGR for the given FDI inflows could be computed by using the below formula,

CAGR $(\mathrm{t} 0, \mathrm{tn})=(\mathrm{V}(\mathrm{tn}) / \mathrm{V}(\mathrm{t} 0)) 1 / \mathrm{tn}-\mathrm{t} 0-1$

Where,

$\mathrm{V}(\mathrm{t} 0)$ : start value,

$\mathrm{V}(\mathrm{tn})$ : finish value,

tn $-\mathrm{t} 0$ : number of years

Table 1 : VOLUME OF FDI INFLOWS

\begin{tabular}{|c|c|c|}
\hline YEAR & $\begin{array}{l}\text { AMOUNT (in US\$ } \\
\text { Millions) }\end{array}$ & $\begin{array}{c}\text { ANNUAL } \\
\text { GROWTH RATE } \\
\text { (in \%) }\end{array}$ \\
\hline $2010-11$ & 37182 & 95.6 \\
\hline $2011-12$ & 38012 & 95.81 \\
\hline $2012-13$ & 38925 & 95.92 \\
\hline $2013-14$ & 39272 & 96.12 \\
\hline $2014-15$ & 40214 & 96.25 \\
\hline $2015-16$ & 41652 & 97.21 \\
\hline $2016-17$ & 41985 & 97.65 \\
\hline $2017-18$ & 42124 & 98.34 \\
\hline $2018-19$ & 45247 & 99.23 \\
\hline CAGR & 2.21 & 0.41 \\
\hline
\end{tabular}

Source: Newsletter SIA, Various issues and Computed

\section{Interpretation}

From the above Table 1, we may find that the FDI inflow into the India before 2010 was at minimal level and the CAGR was with the Compounded Annual Growth Rate showing only
95.60 percent. The amount of FDI inflows during the year 2018 - 19 was higher and it was US\$ 45247 Million and the Annual Growth Rate was $99.23 \%$. The CAGR of FDI Inflows was $2.21 \%$ and the CAGR of AGR was $0.41 \%$ that shows the stagnant growth in the FDI. But in the recent period the more number of Foreign Investments surged into India and they were banned and allowed only at minimal level only into few sectors. The change in FDI pattern was mainly because of the kind of policies. Government of India has adopted over the years and that includes, 'inward looking strategy'; and the dependence of borrowings. During the year 2012 - 13 the FDI inflows amount was 38,925 Million which shows the moderate inflow of FDI into India. Therefore on analyzing the FDI inflows into the country for over 9 years, it is clear that that the CAGR is $2.21 \%$. The government of India has realized the importance of FDI inflows into the India.

\section{ANALYSIS THROUGH ONE - WAY ANOVA}

The below Table 2, explains the One - Way ANOVA is computed to find the values of $f$ and $p$.

Table 2:Computation of One - Way ANOVA

\begin{tabular}{|c|c|c|c|c|}
\hline Source & SS & Df & MS & \\
\hline $\begin{array}{c}\text { Betwee } \\
\text { n-treat } \\
\text { ments }\end{array}$ & $\begin{array}{c}7350412250.4 \\
643\end{array}$ & 1 & $\begin{array}{c}7350412250.4 \\
643\end{array}$ & \\
\hline $\begin{array}{c}\text { Within } \\
\text {-treatm } \\
\text { ents }\end{array}$ & $\begin{array}{c}49971981.252 \\
6\end{array}$ & 16 & 3123248.8283 & $\begin{array}{c}F= \\
2353.45074\end{array}$ \\
\hline Total & $\begin{array}{c}7400384231.7 \\
169\end{array}$ & 17 & & \\
\hline
\end{tabular}

Source: Computed

From the above Table 2, we may infer the test of means " $f$ " and has given with the generalized,

$\mathbf{F}=\mathbf{2 3 5 3 . 4 5 0 7 4}$ which considers the means between the FDI inflows and Annual Growth Rate. The f-ratio value is 2353.45074. The $\mathrm{p}$-value is $<.00001$. The result is significant at $\mathrm{p}<.05$. The df stood at 16 and the Mean Significant was 3123248.8283. The df stood at 1 , and when the Mean Significant was 7350412250.4643 .

\section{KOLMOGOROV-SMIRNOV TEST OF NORMALITY}

For analyzing the Test of Normality researcher has conducted K-S Test to see the normality in the data. The below Table 3 explains the normality.

Table 3:K - S Test

\begin{tabular}{|c|}
\hline Distribution Summary \\
\hline Count : 9 \\
\hline Mean: 40512.55556 \\
\hline Median: 40214 \\
\hline Standard Deviation: 2499.299107 \\
\hline Skewness: 0.581239 \\
\hline Kurtosis: 0.140813 \\
\hline
\end{tabular}

Source: Computed.

The test statistic (D, provides a measurement of the divergence of your sample distribution from the normal distribution. The value of the K-S test statistic (D) is .14516. The higher the value of $\mathrm{D}$, the less probable it is that your data is normally distributed. In this case

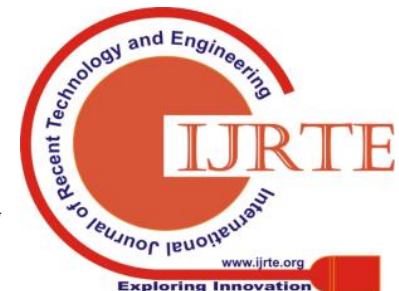


the data does not differ significantly. The p-value quantifies this probability, the value of $p=0.97713$ which defines that the data is normally distributed. The skewness kurtosis stood at 0.140813 which is consistently strong.

\section{FACTORS INFLUENCING FDI IN INDIA}

Some of the factors which predominantly influences the FDI in India as follows,

\section{1) GDP (Gross Domestic Product)}

In India the GDP (Gross Domestic Product) is used as one of the independent variables, which reflects the market potential. In India, the market price is taken into consideration for calculating the GDP and at factor cost. The sum of market values of the final goods and services that are produced in the market are only taken as GDP. There is a direct relationship between the market price and the FDI inflows.

\section{2) Production of Coal}

Coal Production is much important for the production of energy in India. It is the easiest availability of natural resources in the country. According to statistical function the coal is not much important and it has the statistical significance. Coal is the renewable form of energy to the nation. The export of coal is becoming higher and the steel industries are mostly depending on the coal.

\section{3) WAGES}

The study has shown the positive impacts over the human resources the total wages are paid to the workers are chosen as proxy variable. The elasticity between the Total FDI inflows and the wages paid to the workers is moderate.

\section{4) INFLATION RATE}

The economic stability of the country is determined through the inflation of the particular country. The relationship between the FDI and the inflation is as against the expected negative relationship.

\section{5) TRADE OPENNESS}

The government policy has the important role to play with the FDI terms and it determines the FDI inflows into the Nation. The real GDP of that economy is defined as the ratio of total trade to FDI inflows in the particular country.

\section{PROBLEMS FOR LOW FDI}

Among the world, India is the second largest populated country. India is having the high level of speaking English work force, for the foreign investors it is the safest country to invest in diversified industries. Some of the problems are there in FDI in India and that are discussed as follows:-

\section{INADEQUATE INFRASTRUCTURE}

The infrastructure facilities are also the important part of the economic growth in the Nation. Infrastructure facilities are cited as major important hurdle for the FDI inflows. A bottleneck in the infrastructure sector reduces the foreign investors to invest in India. Some of the common problem that we have is Power cuts, which is the important drawback for the reduction of foreign Investment.

\section{LABOUR LAWS}

The Labor laws in India are strict and these laws protect the workers from getting exploited from the empowering entrepreneurs. Firms are in need of approval from both the employees and the government's approval.

\section{LESS EPZ (Export Processing Zones)}

There is a lack in the dynamism in the export processing zones in India because, the of the ambivalence in the protection of FDI in India. Comparing with China the India has failed to develop the zones. The changing incentive patterns that are attached to the zones are also affecting the FDI in India.

\section{CORRUPTION}

In every public service the corruption is prevailing in India, from the supply of ammunitions to the subsidized food for the poor people the generation of power and its transmission. The foreign investors are keeping them away due to misuse of funds, allegations and scams that are prevailing in India.

\section{CORPORATE TAX RATES}

The corporate Tax rates which is prevailing in India is merely very 15 to $30 \%$ with the comparison to the $48 \%$ of the tax in foreign countries. High Corporate Tax is discouraging the foreign investment in India.

\section{SUGGESTIONS TO IMPROVE THE FDI INFLOW INTO INDIA}

1) LABOUR LAWS ARE TO BE FLEXIBLE: The maximum FDI could be seen in China in Manufacturing Sector particularly because it's the hub. Manufacturing Sector could help the country like India for increasing the FDI inflows. In India, manufacturing sector can incline and achieve its position so as to improve the labour standards. More flexible labour laws can be adopted only if country is ready to take the better initiatives.

\section{2) SECT ORAL CAPS}

Though the Sect oral Caps, the government has increased for the FDI over the years. The Coal, retail and real estate sectors are facing the problems. It is suggested to allow more FDI Under the automatic route. SEZ's are to be improved along with roads, ports and connectivity.

\section{3) ENCOURAGE GREENFIELD PROJECTS}

Due to larger Greenfield projects the India's volume of FDI has increased largely. In order to attract more Greenfield projects the business friendly environments are to be generated. Country shall focus on improving the human resource standards and technology.

\section{CONCLUSION}

Foreign Direct Investment plays a predominant role in the upliftment of the nation, particularly the Long Term. For enhancing the competitiveness, the source of capital is also much important and its vital essential for developing the country's economic growth through transfer of technology, increasing the productivity and through creation of new employment opportunities. India is said to be the fifth largest recipient of FDI across the Globe. Even though there is an increase in the Flow of FDI into the nation, the global share of FDI is consistently weak comparing to the other developing countries. Some of the critical issues which we consider for the for the less inflow of FDI are, Lack of good infrastructure, increasing corporate tax rates, less EPZ's, Sect oral gap etc. In order to overcome these situations and circumstances, 
the sect oral Cap needs to be revised by the Indian government. The double Taxation Treaties are to be signed and increase the bilateral trade. The innovative polices and the better corporate governance is to be adopted for attracting more FDI in India. To make it as the developed economy.

\section{REFERENCES}

1. Birendra Kumar, Surya Dev (2003), "Low Bargaining Power of Labour Attracts FDI in India", Social Science Research Network, No.431060, 2003.

2. Sebastin (2004), "A Study of the Regional Determinants of Foreign Direct Investment in India, and the case of Gujarat"," Working Paper No. 2004/03/07, 2004, Indian Institute of Management

3. Peng Hu (2006), "India's suitability for Foreign Direct Investment", Working Paper No.553, 2006, International Business with special reference to India, University of Arizona.

4. Peter (2008), "Foreign Direct Investment and Growth of Manufacturing Sector: An Empirical Study on Post Reforms India", is a doctoral thesis submitted to the University of Mysore, 2005.

5. Arthur, Lokanandha Reddy Irala (2009), "Foreign Direct Investment and Growth of Manufacturing Sector: An Empirical Study on Post Reforms India", is a doctoral thesis submitted to the University of Mysore, 2005

6. Reserve Bank of India, Monthly Bulletin, Various Issues.

7. www.rbi.org/ various issues.

8. www. dipp.nic.in/ various issues.

9. Annual Survey of Industries, Ministry of Statistics and program implementation, Government of India.

10. Secretariat for Industrial Assistance, DIPP, Ministry of Commerce \& Industry, Govt. of India.

11. Department of Economic Affairs, Statistics, Ministry of Finance, Govt. of India.

12. FDI Statistics, Department of Industrial Policy and Promotion, Ministry of Commerce \& Industry, Government of India.

13. R. Anitha (2012). "Foreign Direct Investment And Economic Growth In India". International Journal of Marketing, Financial Services \& Management Research. August 2012. Volume 1. Issue:8. ISSN: 2277 3622. Pp. 1 - 6.

14. Chigbu Ezegi, et. al (2015), Impact of Capital Inflows on Economic Growth of Developing Countries, International Journal of Management Science and Business Administration, Vol. 1, Issue - 7, June 2015, Pp. 2-5. 